\title{
The use of circumlocution in the foreign language context $^{1}$
}

\author{
Patricia Salazar Campillo (LAELA) \\ Departament d'Estudis Anglesos \\ Facultat de Ciènces Humanes i Socials \\ Universitat Jaume I
}

Received: 20 March 2005 / Accepted version: 30 May 2005

ISSN: 1697-7467

\begin{abstract}
The present article reports on a study carried out among non-native speakers of English as a foreign language who made use of a series of compensatory strategies (circumlocution) when faced with unknown lexical items. According to the results, this particular kind of strategies proved to be especially useful to solve gaps in communication in order to keep the flow of conversation. From our findings, some pedagogical remarks derive which point to the facilitative role of compensatory strategies as a tool to cope with problematic vocabulary.
\end{abstract}

Key words: compensatory strategies, circumlocution, lexicon.

RESUMEN: El presente estudio se centra en el uso que hicieron seis hablantes de inglés como lengua extranjera de estrategias compensatorias (circunloquios) cuando tuvieron que describir vocabulario nuevo. Según muestran los resultados, esta particular clase de estrategias comunicativas fueron especialmente útiles para resolver dificultades léxicas. Una serie de implicaciones pedagógicas se desprenden de nuestros resultados, las cuales apuntan al papel altamente positivo de las estrategias compensatorias como herramienta disponible para estudiantes de lenguas extranjeras al tratar de expresar léxico nuevo o problemático.

Palabras clave: estrategias compensatorias, circunloquios, léxico.

\section{INTRODUCTION}

Bearing in mind that one of the main functions of spoken language is the transference of information, it is essential that interlocutors in the conversation are able to express what they really want to say. In Brown and Yule's (1983: 13) words: "When the message is the reason for speaking, then the message must be understood". However, there are cases in which conversation does not progress smoothly; for example in conversations involving non-

${ }^{1}$ This study is part of a research project funded by a grant from the Spanish Ministerio de Educación y Ciencia (HUM2004-04435/FILO), co-funded by FEDER, and a grant form Fundació Universitat Jaume I and Caixa Castelló-Bancaixa (P1.1B2004-34). 
native speakers. The problem they confront is to explain what they mean when they do not have the right word in their vocabulary. In fact, when communication breaks down and negotiation of meaning is needed, the type of repairs that take place are mainly lexical, as these are key elements for successful communication. For this reason, a number of studies have focused on lexical items and acquisition of a second (L2) or foreign language (FL) (e.g., Ellis et al., 1994; Loschky, 1994; de la Fuente, 2002). These studies provide contradictory findings: on the one hand, Loschky's (1994) study found positive effects of negotiation on vocabulary comprehension but not on acquisition. On the other hand, Ellis et al. (1994) and de la Fuente (2002) corroborate the fact that negotiation resulted in better comprehension and acquisition of new lexical items.

When L2/FL learners negotiate unknown or forgotten vocabulary, they are making use of a part of their communicative competence known as strategic competence or, according to Swain (1984: 189) "the mastery of communication strategies that may be called into action either to enhance the effectiveness of communication or to compensate for breakdowns in communication." The concept of communicative competence has been developed, among others, by Canale (1983) and Celce-Murcia, Dörnyei and Thurrell (1995). In 1983 Canale proposed a model of communicative competence which consisted of four components: grammatical competence (the knowledge of the language code), sociolinguistic competence (the appropriate application of politeness, etc.), discourse competence (the ability to combine language structures into different types of cohesive texts) and strategic competence, which was defined as the knowledge of communicative strategies to overcome communicative breakdowns. In the 90s, Celce-Murcia et al. developed their own model of communicative competence, in which strategic competence included "... (an) inventory of skills that allows a strategically competent speaker to negotiate messages and resolve problems or to compensate for deficiencies" (1995: 9). As shown by these models of communicative competence, successful L2/FL learners may use their strategic competence to keep conversation going when problems arise. Most of these problems are lexical, as the number of unknown words always seems to outnumber the number of known items (Cohen, 1991). In this case, the words the learners employ try to compensate for the lexical terms they ignore. According to Faerch and Kasper (1983), there exists a subset of communication strategies, known as compensatory strategies ( $\mathrm{CpS}$, henceforth), which are used to keep the meaning of the learner's original communicative purpose. We turn to discuss $\mathrm{CpS}$ in the next section.

\section{Compensatory Strategies}

This type of strategies are used to overcome troubles in the production of lexis, that is to say, the speaker wants to communicate an intended meaning but he/she has no word for it. Facing vocabulary deficiencies is a common situation in native speaker (NS)/non-native speaker (NNS) or NNS/NNS conversations, where non-native speakers need to compensate for these deficiencies in order to achieve fruitful communication.

The emphasis on lexis is a consequence of the definitional characteristic of problematicity of compensatory strategies. For this reason, in this study, we will be dealing with lexical compensatory strategies, in that they replace missing lexical terms. Compensatory strategies have been defined by Poulisse (1990: 192-193) as: "processes, operating on conceptual and linguistic knowledge representations, which are adopted by language users in the creation of 
alternative means of expression when linguistic shortcomings make it impossible for them to communicate their intended meanings in the preferred manner". That is to say, $\mathrm{CpS}$ are used when the speaker has to resort to solutions to bridge lexical gaps to get his/her message through. This can be achieved by means of circumlocution, which is a strategy learners may use in order to solve a vocabulary problem. Tarone (1983: 62) defined circumlocution like this: "The learner describes the characteristics or elements of the object or action". In turn, Paribakht (1985) divided circumlocution into physical descriptions, constituent features, locational and historical properties and functional descriptions, among others. In a study which focused on the use of circumlocutions, Masters and Marsal (1997) show that if learners are encouraged to centre on the salient features of lexical items, they are able to circumlocute in a better way.

\section{The STUDY}

The study we carried out was first motivated by the obvious essential role of lexis in any developing linguistic system. Indeed, most negotiations of meaning revolve around key elements whose misinterpretations may impair or inhibit communications. These key elements are often lexical terms. As reported by Pica et al. (1993), negotiation for meaning is far more likely to concern lexical items than morphology. In the same line, Mackey et al.'s (2000) study demonstrated that most of the feedback learners received was triggered by problems with lexis.

The second motivation stems from Kellerman's (1991: 143) words: "learners seem more able to reflect on lexical difficulties than those involving other types of linguistic element". Moreover, as FL learners may lack vocabulary in the target language, their communicative success relies entirely on their "ability to communicate within restrictions" (Savignon, 1983: 43) by using strategies. These strategies may be used "either to enhance the effectiveness of communication or to compensate for breakdowns in communication" (Swain, 1984: 189). In order to avoid a type of problematic communication known as communication breakoff (Varonis and Gass, 1991), learners have to provide comprehensible input by means of negotiating meaning.

Drawing on Swain's (1984) and Varonis and Gass's (1991) above-mentioned statements, the present study aimed at examining the following two objectives: First, we wished to analyse how unknown vocabulary was made comprehensible to the addressee. Specifically, we wanted to find out how circumlocution was used by non-native speakers of English when facing the task of explaining new lexical items.

The second objective was the elaboration of a possible classification of circumlocution into different categories, according to its use.

\section{Participants}

The participants of the present study were six Spanish girls whose ages ranged from 15 to 18 years old. Some common characteristics they shared were: (i) their level of English was intermediate, (ii) none of them had visited any English-speaking country, and (iii) they were attending three hours a week of formal instruction of English as-a-foreign language in secondary schools. 
The researcher was a 25-year-old Spanish teacher with a degree in English Philology. She had high proficiency in English and had visited England several times.

\section{Procedure}

The data of this study were collected for the purposes of an earlier project (see Salazar, 2003) which aimed at analysing the effects of negotiation of meaning on second language comprehension and acquisition. We have culled examples from the transcripts and used them for the purposes of this research. In order to collect our data, the subjects had to perform three tasks: in Task 1, the researcher gave instructions about the placement of 15 drawn items (mug, loud speaker, ashtray, stool, rug, fan, vase, socket, stool, felt tip pen, stapler, sharpener, bulb, directory and frame) on an office setting. In this first task, negotiation of meaning was allowed so that (1) the participants could choose the correct item, and (2) they could identify the right location. The subjects were warned that the items did not need to be placed in a logical position. Their respective sheets with the office setting were visually separated and the conversation was tape-recorded. Task 1 was considered to have finished when the six participants acknowledged they had placed the 15 items.

The purpose of this first task was both the recognition and placement (correctly or not) of the objects through negotiation of meaning. On negotiating the potentially unknown lexical items, we expected the participants would draw their attention upon them. Moreover, the correct or incorrect placement of the objects was a measure of the subjects' ability to comprehend the instructions. Example 1 illustrates the type of exchanges that took place in Task 1:

\section{Example 1}

Researcher: Put the ashtray on the shelf

Student 1: What is the ashtray?

R: Ashtray? Imagine, if you smoke, you need an ashtray to leave your cigarette when you finish it. Do you understand?

S1: Yes

S6: Where I can put the ashtray?

R: The ashtray... on the shelf. Right? The second. Put the rug on the floor.

In Task 2, the participants were told where to place the items again, but this time they had a different position from Task 1. Negotiation of meaning was not allowed in this task and there was no tape recording. This task finished when the subjects told they had placed the items they remembered on their sheets of paper. The aim of Task 2 was to check whether the negotiated items in Task 1 were remembered by the subjects. We allowed a one-week interval between Task 1 and 2 .

One week later, subjects carried out Task 3 in pairs. One member of the dyad arranged freely the objects on a bedroom setting and she had to explain to her partner what object to choose and where to place it. Afterwards, they changed roles. In this last task, meaning negotiation could be used and there was tape-recording. The goal of this last task was to focus on the participants' output, that is to say, whether or not they could produce the name of the items they had negotiated in Task 1 . Therefore, in Task 3 there was no researcher's intervention, 
as she was simply an observer. The following example provides an illustration of the negotiation of meaning for mug between Student 2 and 3:

\section{Example 2}

Student 2: Put the mug?

Student 3: What is mug?

S2: It's a... it's a kind of cup... cup... when you have coffee

S3: Ah

S2: You put it in a cup. This is a kind of cup which it's more

S3: OK

S2: More big. Put this mug on the small table.

\section{Coding And analysis of the data}

As mentioned earlier, one goal of the present study was to ascertain the use and nature of circumlocution by NNSs when confronted with new vocabulary. To this end, we counted the number of circumlocutions in Task 1, which were produced by the researcher, and in Task 3 , where circumlocutions stemmed from the subjects' exchanges.

\section{RESULTS AND DISCUSSION}

Table 1 illustrates the distribution of the researcher's circumlocutions in Task $1(n=22)$.

Table 1. Researcher's circumlocutions in Task 1.

\begin{tabular}{|c|c|c|c|}
\hline Function & Combination & Description & Superordinate \\
\hline $9(41 \%)$ & $8 *(36.3 \%)$ & $4(18.1 \%)$ & $1(4.5 \%)$ \\
\hline
\end{tabular}

* Combination included 2 instances of superordinate + function, 5 of description + function, and 1 of part of the whole + description.

The second objective of the present study was to create a classification of circumlocution into categories. In this sense, four categories are distinguished: first, the category of function, in which an explanation of the purpose of the targeted object is provided, as Example 3 shows:

\section{Example 3}

Researcher: Put the felt tip pen on the keyboard

Student 3: Who is this?

$\mathrm{R}$ : The felt tip pen is a kind of pen you can write with. You can write very thick letters with it 
The second category is combination, which merges some other categories (see Example 4):

\section{Example 4}

Researcher: What don't you understand? Fan or rug?

Student 3: Rug the rug

$\mathrm{R}$ : A rug is something made of cloth you put on the floor and you can put your feet on

As illustrated by the following example, the third category involves the description of the features of the item:

\section{Example 5}

Researcher: Put the drawer on the filing cabinet

Student 1: What is the drawer?

$\mathrm{R}$ : A drawer is something square, made of wood

Finally, we find the category of superordinate, which is the use of a general word:

\section{Example 6}

Researcher: Place the stool on the right of the big table

Student 4: What is the stool?

$\mathrm{R}$ : The stool is a kind of chair

According to our results, the highest percentage of category use belongs to the function of the object, followed by the combination type, the description of the object and finally, the use of a superordinate. The predominance of functional descriptions is reported in some other studies (e.g. Bialystok, 1983), and it reflects the high number of concrete objects that have to be communicated in the L2. Kellerman et al. (1987) further argue that it is the feature of function what differentiates one object from another; however, if a learner has to explain an abstract concept, the characteristic of function is not likely to appear much. In this line, a study carried out by Paribakht (1985), in which the participants had to describe notions like Love or Justice, learners made more use of contextual support and knowledge of the world than they did with concrete objects, where descriptions of properties were more often used. In the present study there were no instances of abstract terms, so we found a large number of functional descriptions.

As can be seen in Table 2, the category of function was also the most used by the six participants of the study. Out of a total of 76 circumlocutions on the subjects' part, 50 referred to the function carried out by the object they were explaining. This category was followed by the use of superordinates, then combination and finally, with only one example each, the categories of description and location. In this last category, the learners explained where one item was usually placed, as the following exchange shows. Here, Student 3 is trying to explain the meaning of rug. 


\section{Example 7}

Student 3: And put the... the... the ashtray? No... it's the same as... it's for... this thing put... normally place where I put is near the bed and... Do you understand?

Student 2: Yes

Table 2. Students' circumlocutions in Task 3.

\begin{tabular}{|c|c|c|c|c|}
\hline Function & Superordinate & Combination & Description & Location \\
\hline $50(65.7 \%)$ & $18(23.6 \%)$ & $6^{*}(8 \%)$ & $1(1.3 \%)$ & $1(1.3 \%)$ \\
\hline
\end{tabular}

* All the combinations were function + description.

The results of this study have demonstrated that our participants, not having the lexical term available for retrieval in the suggested task, were nevertheless able to compensate for this lack by means of the use of circumlocutions. These involved the descriptions of the properties of the referent, such as its function, shape, colour or location. Our learners' circumlocutions can be considered as compensation labels which share enough attributes with the targeted item. Moreover, in some cases, some strategies were embedded within other strategies, as in the category of combination. Our research shows that circumlocution is a strategy FL learners are prone to employ when faced with vocabulary problems. Although it may be regarded as a pilot study, it also provides the starting point for future research investigating the use and nature of circumlocution not only in the FL context, but also in the L2 context.

Our participants' behaviour in choosing the array of strategies shown in Table 2 has got strong implications for the educational setting, as we should teach L2/FL learners how to manage problematic vocabulary when confronted with it. Indeed, L2/FL students could become better strategy users through training. As argued by Alcón (2004), the teaching of linguistic competence, that is, the teaching of grammar, vocabulary and pronunciation is not enough to develop learners' strategic competence. Therefore, there is a need to focus also on strategic competence in language teaching. In this sense, if we teach this type of competence, we may help our learners to use strategies to overcome inhibitions and/or resistance when facing unknown lexical items in the L2/FL. We are thus supporting views that favour the teaching of communication strategies by means of the provision of classroom activities and tasks in which learners develop a range of abilities in the L2/FL. In Bialystok's (1990: 141) words: "any instruction that helps students to master part of the language or to become more comfortable using it is to be commended and not criticized".

The teaching of some general, basic words may aid participants in conversations to sort out difficulties in negotiating meaning. As reported by Robinson (1989), some general words can be pronouns such as he, they, etc. and verbs like do, make or get. This author has also argued that for a long time in vocabulary teaching, the emphasis has been on the accumulation and memorization of lists of new words which are used to fill in a gap in a sentence. However, if we teach our learners strategies for using procedural words to paraphrase the meanings of more specific or technical words, we may enhance their strategic competence by 
means of developing procedural before declarative knowledge. The teaching of some core words may be, to our mind, useful and desirable in order to make our students better strategy users. This is in line with Tarone and Yule's (1989) remarks that in circumlocution, learners are required to use certain basic core vocabulary and sentence structure to describe properties and function of an item. In our research, although the six learners had not been instructed in the use of basic vocabulary in order to explain new meanings, they were nevertheless capable of making their output comprehensible by resorting to basic vocabulary and functional descriptions.

\section{Conclusion}

According to our results, the use of circumlocutions was broad in the foreign language context the study took place. Both the researcher and the subjects employed them to explain the meaning of unknown vocabulary items. In addition, the category of function was highly used in dealing with lexical difficulties. Our findings are consonant with other results (e.g. Bialystok, 1983; Yule and Tarone, 1990) showing that the strategies of function (The thing for pencils) and description (It's a thing made of wood) are the most employed ones when learners do not know the appropriate word in the L2/FL. Other strategies, such as the use of superordinates (The cup) are also taken into account. The present study thus corroborates previous findings which show that learners make use of analytic strategies that select properties of the referent when facing unknown vocabulary. Nevertheless, this study suffers from a number of limitations, which are as follows: first, we did not carry out a pre-test in order to ascertain the strategic competence of our learners; second, there was no control group, which may have shed some light on the effectiveness of the tasks. A third limitation is the small sample size (six participants). Further limitations concern the gender of the participants, as we only had female learners, and the age of the subjects (teenagers); this means that we do not know how older or younger learners would have performed the tasks.

Our study is also limited in the sense that the tasks focused on real-world concepts, with no reference to abstract terms. Therefore, as our results show, there was a predominance of functional descriptions, a fact that is not surprising because most concrete objects have a function. As a corollary of our findings we have suggested that some training on the use of $\mathrm{CpS}$ would enhance both learners' strategic competence and positive reactions to face vocabulary problems when communicating in the L2/FL.

\section{REFERENCES}

Alcón, E. (2004). "Research on language and learning: Implications for language teaching", in International Journal of English Studies, 4: 173-196.

Bialystok, E. (1983). "Some factors in the selection and implementation of communication strategies", in C. Faerch and G. Kasper (eds.), Strategies in Interlanguage Communication. London: Longman, 100-118.

Bialystok, E. (1990). Communication Strategies: A psychological Analysis of Second-language use. Oxford: Blackwell. 
Brown, G. and Yule, G. (1983). Teaching the Spoken Language. Cambridge: Cambridge University Press.

Canale, M. (1983). "From communicative competence to communicative language pedagogy", in J. C. Richards and R. Schmidt (eds.), Language and communication. New York: Longman, 2-28.

Celce-Murcia, M., Z. Dörnyei, \& S. Thurrell (1995). "Communicative competence: A pedagogically motivated model with content specifications", in Issues in Applied Linguistics, 6: 5-35.

Cohen, A. (1991). "Strategies in second language learning: Insights from research", in R. Phillipson, E. Kellerman, L. Selinker, M. Sharwood Smith, and M. Swain (eds.), Foreign/second language pedagogy research. Clevedon: Multilingual Matters, 107-119.

De la Fuente, M ${ }^{\mathrm{a}}$. J. (2002). "Negotiation and oral acquisition of L2 vocabulary", in Studies in Second Language Acquisition, 24: 81-112.

Ellis, R., Tanaka, Y. and Yamazaki, A. (1994). "Classroom interaction, comprehension and L2 vocabulary acquisition", in Language Learning, 44: 449-491.

Faerch, C. and Kasper, G. (1983). Strategies in Interlanguage Communication. London: Longman.

Kellerman, E. (1991). "Compensatory strategies in second language research: A critique, a revision, and some (non-)implications for the classroom", in R. Phillipson, E. Kellerman, L. Selinker, M. Sharwood Smith, and M. Swain (eds.), Foreign/second language pedagogy research. Clevedon: Multilingual Matters, 142-161.

Kellerman, E., Bongaerts, T. and Poulisse, N. (1987). "Strategy and system in L2 referential communication", in R. Ellis (ed.), Second language acquisition in context. London: Prentice Hall, 100-112.

Loschky, L. (1994). "Comprehensible input and second language acquisition. What is the relationship?", in Studies in Second Language Acquisition, 16: 303-323.

Mackey, A., Gass, S. \& McDonough, K. (2000). "How do learners perceive interactional feedback?", in Studies in Second Language Acquisition, 22: 471-497.

Masters, A. \& Marsal, F. (1997). "How to avoid language breakdown? Circumlocution!", in Foreign Language Annals, 30: 473-484.

Paribakht, T. (1985). "Strategic competence and language proficiency", in Applied Linguistics, 6: 132-146.

Pica, T., Kanagy, R. and Falodun, J. (1993). "Choosing and using communication tasks for second language instruction", in S. Crookes and S. Gass (eds.), Tasks and language learning: Integrating theory and practice. Clevedon: Multilingual Matters, 9-34.

Poulisse, N. (1990). The Use of Compensatory Strategies by Dutch Learners of English. Dordrecht: Foris.

Robinson, P. (1989). "A rich view of lexical competence", in ELT Journal, 43: 274-282.

Salazar, P. (2003). "The effects of comprehensible input on the process of language learning: A case study", in Rassegna Italiana di Lingüistica Aplicata, 3: 161-173.

Savignon, S. J. (1983). Communicative competence: Theory and classroom practice. Reading, MA: Addison-Wesley.

Swain, M. (1984). "Large-scale communicative language testing: A case study", in S. Savignon and M. Berns (eds.), Initiatives in communicative teaching. Reading, MA: Addison-Wesley, 185-201.

Tarone, E. (1983). "Some thoughts on the notion of "communication strategy", in C. Faerch and G. Kasper (eds.), Strategies in interlanguage communication. London: Longman, 61-74.

Tarone, E. and Yule, G. (1989). Focus on the Language Learner. Oxford: Oxford University Press.

Yule G. and Tarone, E. (1990). "Eliciting the performance of strategic competence", in R. Scarcella, E. Andersen and S. Krashen (eds.), Developing communicative competence in a second language. New York: Newbury House, 179-194. 